\title{
AN ECONOMIC ANALYSIS OF TRANSNATIONAL BANKRUPTCIES*
}

\author{
LUCIAN ARYE BEBCHUK \\ Harvard Law School
}

and

\author{
ANDREW T. GUZMAN \\ University of \\ California, Berkeley
}

\begin{abstract}
This paper analyzes the effects of the legal rules governing transnational bankruptcies. We compare a regime of "territoriality" - in which assets are adjudicated by the jurisdiction in which they are located at the time of the bankruptcy-with a regime of "universality" - in which all assets are adjudicated in a single jurisdiction. Territoriality is shown to generate a distortion in investment patterns that might lead to an inefficient allocation of capital across countries. We also analyze who gains and who loses from territoriality, explain why countries engage in it even though it reduces global welfare, and identify what can be done to achieve universality.
\end{abstract}

\section{INTRODUCTION}

B USINESSES operate across borders. When those businesses fail, assets and creditors are often located in multiple jurisdictions. Bankruptcy laws, however, are national in character and, therefore, poorly designed to handle cross-border bankruptcies.

It is clear that transnational bankruptcies are of increasing importance and that the existing legal infrastructure is ill equipped to deal with them. In the Maxwell Communications case, for example, a British holding company with hundreds of subsidiaries failed. ${ }^{1}$ The bulk of the firm's assets

* For helpful comments and conversations, we are grateful to Richard Caves, Stephen Choi, Christine Jolls, Aart Kraay, Erik Kramer, Lynn LoPucki, Howard Radzely, Alan Sykes, Eric Talley, Elizabeth Warren, and participants at the 1997 American Law and Economics Association annual meetings and the UCLA conference "Political Economy of Contractual Obligations: The Case of Bankruptcy Law." For financial support, Lucian Bebchuk thanks the National Science Foundation and the John M. Olin Center for Law, Economics, and Business; Andrew Guzman thanks the Sheldon Seevak Fellowship.

1 A more detailed discussion of the Maxwell case is provided in Jay L. Westbrook, The Lessons of Maxwell Communications, 64 Fordham L. Rev. 2531, 2534-40 (1996). See also Mike Sigal et al., The Law and Practice of International Insolvencies, including a Draft Cross-Border Insolvency Concordat, in 1 1994-1995 Annual Survey of Bankruptcy Law 8995 (1994); Richard A. Gitlin \& Ronald J. Silverman, International Insolvency and the Maxwell Communication Corporation Case, in International Bankruptcies: Developing Practical Strategies 7, 21-47 (Practicing Law Institute Series No. 628, 1992).

[Journal of Law and Economics, vol. XLII (October 1999)]

(C) 1999 by The University of Chicago. All rights reserved. 0022-2186/1999/4202-0008\$01.50 
were located in the United States, while the majority of its creditors and its headquarters were in Britain. ${ }^{2}$ Maxwell Communications Corporation (MCC) had, among other holdings, 100 percent ownership of Macmillan, Inc., a publishing company purchased in 1988 for $\$ 2.6$ billion, and the Official Airlines Guide (OAG), acquired for $\$ 750$ million in the same year. ${ }^{3}$ The absence of a coherent international system for dealing with the failure of MCC led to the filing of a Chapter 11 bankruptcy in the United States and an administration in Britain. Neither court system was prepared to relinquish control over the assets within its jurisdiction, and no procedure existed for simultaneous proceedings in the two countries. Only through an ad hoc cooperative arrangement between the courts of the United States and Britain was order brought to the proceedings. ${ }^{4}$

Similar problems of jurisdiction and coordination were present in the other blockbuster bankruptcies of the decade-the Bank of Credit and Commerce International (BCCI) case involving some $\$ 20$ billion in assets and operations in 69 countries, ${ }^{5}$ and the Olympia and York case that featured debts of some $\$ 12$ billion owed to creditors in several countries. ${ }^{6}$ In each case, informal, ad hoc cooperation by courts and regulators was needed to resolve the issues arising from the transnational character of the failure.

Of course, the above mentioned bankruptcies represent only the largest and most conspicuous failures. Many smaller bankruptcies find their way into the court system or are resolved in the shadow of the current system of poorly conceived and inconsistently administered rules for transnational bankruptcies. These cases face difficulties similar to those of the largest bankruptcies but typically cannot rely on ad hoc solutions to these problems. $^{\text {? }}$

The need for a coherent and effective international bankruptcy system is

2 See In re Maxwell Communication Corp., 93 F.3d 1036, 1040 (2d Cir. 1996).

${ }^{3}$ See In re Maxwell Communications Corp., 170 B.R. 800, 802 (Bankr. S.D.N.Y. 1994).

${ }^{4}$ Needless to say, a similar bankruptcy with smaller stakes might not enjoy the benefit of such an arrangement.

${ }^{5}$ See Duncan E. Alford, Basle Committee Minimum Standards: International Regulatory Response to the Failure of BCCI, 26 Geo. Wash. J. Int'l L. \& Econ. 241, 258 (1992).

- See Patrick Lannin, UK Administration Would Hand Control to Courts, Reuters, May 15, 1992, at Fin. Rep. (discussing the O \& Y case); E. Bruce Leonard \& R. Gordon Marantz, Cross-Border Issues between the United States and Canada, in International Bankruptcies: Developing Practical Strategies, supra note 1, at 439.

${ }^{7}$ See, for example, In re Ocana, 151 B.R. 670 (S.D.N.Y. 1993); In re Petition of Smouha, 136 B.R. 921 (S.D.N.Y. 1992), appeal dismissed without opinion, 979 F.2d 845 (2d Cir. N.Y. 1992); In re Petition of Shavit, 197 B.R. 763 (Bankr. S.D. N.Y. 1996); Petition of Ward, 201 B.R. 357 (Bankr. S.D.N.Y. 1996); In re Shavit, 197 B.R. 763 (Bankr. S.D.N.Y. 1996); In re Grandote Country Club Co., Ltd., 200 B.R. 218 (D. Colo. 1997). 
an inevitable result of the growth in international business activity. The volume of international business activity has increased steadily for decades and continues to do so. For example, from 1985 to 1995 , the global flow of foreign direct investment grew from $\$ 60$ billion to $\$ 315$ billion. ${ }^{8}$ Similarly, the stock of foreign direct investment grew at an annual rate of 11 percent in real terms from 1980 to $1993 .{ }^{9}$ With more and more capital crossing national borders, more transnational firms exist and, therefore, more transnational bankruptcies come about.

The large and growing amount of transnational activity and recent experiences with large bankruptcies demonstrate that the continuing internationalization of commercial dealings demands some form of international bankruptcy procedures. ${ }^{10}$ There is a general consensus that the current legal approach to such insolvencies - territoriality-is unsatisfactory. "Territoriality, also known in derogatory fashion as the "grab rule," involves the seizure of assets by the courts of the jurisdiction in which those assets are found at the time of the bankruptcy filing. The courts in question then dis-

\footnotetext{
${ }^{8}$ See World Trade Organization Secretariat, Trade and Foreign Direct Investment, Press/ 57 (press release, October 9,1996 ).

9 See, for example, Andrew T. Guzman, Why LDCs Sign Treaties That Hurt Them: Explaining the Popularity of Bilateral Investment Treaties, 38 Va. J. Int'l L. 639, 640-41 (1998). A survey of American multinationals, conducted by the Bureau of Economic Analysis of the U.S. Department of Commerce in 1989, revealed that in a group of 58 countries, the median number of affiliates of U.S. multinationals is 113 , while the median average value of assets per affiliate is $\$ 45$ million. See Mihir A. Desai, A Multinational Perspective on Capital Structure Choice and Internal Capital Markets 17 (unpublished manuscript, Harvard Univ., Dep't Econ. 1997).
}

${ }^{10}$ Some initiatives have taken place in an effort to find solutions to the challenges posed by transnational insolvencies. One such attempt is the American Law Institute (ALI) Insolvency Project. This project is attempting to produce an outline of the insolvency laws of Canada, the United States, and Mexico. It is hoped that with these documents in hand, the project will then be able to generate ideas for specific cooperative procedures to deal with international insolvencies. For a more detailed discussion of the ALI project, see Jay L. Westbrook, Creating International Insolvency Law, 70 Am. Bankr. L. J. 563, 564-69 (1996). Other significant efforts include the Concordat of the International Bar Association, which establishes principles relating to international insolvencies (see Anne Nielsen, Mike Sigal, \& Karen Wagner, The Cross-Border Insolvency Concordat: Principles to Facilitate the Resolution of International Insolvencies, 70 Am. Bankr. L. J. 533 (1996)); the project undertaken by the United Nations Commission on International Trade Law (UNCITRAL), a conference that meets twice a year and is expected to produce a model law or convention (see Westbrook, supra, at 569-73); and the European Union Convention on Insolvency Proceedings (see Manfred Balz, The European Convention on Insolvency Proceedings, 70 Am. Bankr. L. J. 485 (1996)).

"See, for example, Jay L. Westbrook, Choice of Avoidance Law in Global Insolvencies, 17 Brook. J. Int'l L. 499, 516 (1991) ("There is almost unanimous agreement that more international cooperation ... is required"). Robert K. Rasmussen, A New Approach to Transnational Insolvencies, 19 Mich. J. Int'l L. 1 (1997). But see Lynn M. LoPucki, Cooperation in International Bankruptcy: A Post-universalist Perspective, 84 Cornell L. Rev. 696 (1999) (defending territorialism). 
tribute the assets according to local rules. The most popular defense of the grab rule is that it provides benefits to certain parties, especially local creditors who are spared the inconvenience and expense of litigating in a distant forum. ${ }^{12}$

The alternative rule, universalism, favors the settlement of bankruptcy within a single "main" jurisdiction. Other jurisdictions turn the assets of the bankrupt corporation over to this "primary" jurisdiction and the case is dealt with under the latter's laws. ${ }^{13}$ The case against the grab rule and in favor of universalism typically points to the reduction in costs associated with a single adjudication and distribution of the bankrupt entity's assets ${ }^{14}$ and the increased fairness of such a proceeding. ${ }^{15}$

This paper presents a systematic analysis of the choice between territoriality and universality. We demonstrate that the choice of legal regime not only affects the distribution of assets when there is a bankruptcy but also has an ex ante effect on the allocation of capital. More specifically, territoriality leads to a distortion of the capital allocation decision while universality avoids the distortion and leads to a more efficient allocation of capital. This ex ante perspective has, until now, been missing from the debate on transnational bankruptcies. The existing literature focuses almost exclusively on the ex post impact of the grab rule on local creditors. ${ }^{16}$

The paper demonstrates that the efficiency cost of the grab rule may be

12 "[G]rab rule proceedings yield inequitable results. Creditors appearing before the courts that have grabbed the most assets fare better than creditors generally." Todd Kraft \& Allison Aranson, Transnational Bankruptcies: Section 304 and Beyond, 1993 Colum. Bus. L. Rev. 329-64 (1993).

13 Universalism and territoriality are, of course, merely the extreme points on a spectrum. Both terms are sometimes used to refer to arrangements that lie between these two poles. See Westbrook, supra note 11, at 513-19 (describing territorialism, universalism, and variations).

14 "Transactional Gain[s] rest[] upon the benefits to local citizens from the increased flow of trade at lower transaction costs that would result from a coherent system of transnational management of default. ... [T] [Te increased predictability of the results of default would significantly reduce the costs of borrowing." Jay L. Westbrook, Theory and Practice in Global Insolvencies: Choice of Law and Choice of Forum, 65 Am. Bankr. L. J. 457, 466 (1991).

15 "'[I]t is fair to say that the primary effect of the Grab Rule is to protect the primacy of local procedures and local law, with local creditors and sophisticated multinationals sharing significant practical advantages as a result." Westbrook, supra note 11, at 514 .

${ }^{16}$ It is worth noting that the current debate dealing with domestic bankruptcies has recognized the importance of ex ante analysis and has shifted to focus on it. See, for example, Barry E. Adler, A Re-examination of Near Bankruptcy Investment Incentives, 62 U. Chi. L. Rev. 575 (1995); Lucian A. Bebchuk, The Effects of Chapter 11 and Debt Renegotiation on Ex Ante Corporate Decisions (Discussion Paper Ser. No. 104, Harvard Law School Program in Law and Economics 1994); Lucian A. Bebchuk \& Randall C. Picker, Bankruptcy Rules, Managerial Entrenchment, and Firm-Specific Human Capital (John M. Olin Program in Law and Economics Working Paper No. 16, 2d ser., 1992); Douglas 'G. Baird, The Uneasy Case for Corporate Reorganizations, 15 J. Legal Stud. 127 (1986). 
much greater than has previously been realized. In addition to the often discussed costs of uncertainty and multiple adjudications, a rule that systematically favors some creditors over others ex post can lead to inefficient investment. Rules designed to protect the interests of local creditors in the adjudication of bankruptcies may have harmful results on the allocation of capital across countries by causing suboptimal investment by multinational firms. Because territorial rules make the outcome of a bankruptcy (from the point of view of a creditor) depend on the distribution of debt and assets across countries, the interest rate demanded by creditors in exchange for loans will depend on that distribution. By borrowing strategically, firms with existing debt are able to use such territorialist legislation to confer senior status on new creditors, who will therefore offer an interest rate discount. This will come at the expense of old creditors who are already committed to a particular interest rate. ${ }^{17}$ Firms will, in some cases, choose not to invest in the country offering the greatest return on investment, accepting instead a lower return in exchange for a lower interest rate on loans. This strategic investment will generate a deadweight loss for society.

We also identify who stands to gain and who stands to lose from territoriality. Contrary to what is often claimed, territoriality will fail to benefit a country's creditors as long as domestic and foreign lenders adjust the terms of their loans in light of the legal regime in place. ${ }^{18}$ If it is known that local creditors will have an advantage in bankruptcy, those lenders will be willing to accept a lower interest rate, while foreign lenders will demand a higher interest rate. ${ }^{19}$ Nor will local creditors be able to lend more due to these lower rates-the borrower will be indifferent between local and foreign credit because any interest rate gains it gets from local creditors will be exactly offset by increases in the interest rate of foreign creditors. ${ }^{20}$ The

${ }^{17}$ If the old creditors anticipate this strategic borrowing, they may charge a higher interest rate ex ante. This will not affect our results. We assume that fully contingent contracts are not possible due to informational problems. See Section VF infra (considering private solutions to the problem).

${ }^{18}$ In this paper we make the simplifying assumption that all creditors are able to adjust the terms of their loans to the legal regime. For a defense of universalism in the presence of nonadjusting creditors, see Andrew T. Guzman, In Defense of Universalism in Transnational Bankruptcies (mimeographed, 1999; on file with authors), arguing that in the presence of nonadjusting creditors universalism remains the preferred approach to transnational bankruptcies. Nonadjusting creditors (for example, tort claimants) are not able to adjust to the legal regime. For this reason, local involuntary creditors may benefit from territorialism.

${ }^{19}$ It need not be the interest rate that adjusts to the legal regime. Creditors could also change the other terms of the loan. For simplicity, however, we focus on the interest rate.

${ }^{20}$ In other words, the interest rate offered by local creditors is a function of the proportion of total assets acquired through a foreign loan, and the interest rate offered by foreign creditors is a function of the proportion of assets acquired through a local loan. The relationship between these interest rates is such that the average cost of capital for the firm will always be equal to the world rate. 
average cost of capital to the firm will be independent of the composition of the borrowing.

Our results show, however, that a territorialist country, all else equal, can benefit from territorialism if we assume that investment carries with it positive spillovers such as employment, technology, taxes, and so on. The losers-the ones who pay for the benefits gained by the territorialist country and the deadweight loss that is generated-are foreign firms.

In light of the above finding, we are able to draw certain conclusions about the "political economy" that is at work. Territorialism is inefficient and reduces global welfare, but each country, acting individually, has an incentive to adopt a territorialist regime. This highlights the need for a reciprocity requirement or, ideally, international treaties on the subject. ${ }^{21}$

Before proceeding, it is worth highlighting why the issues on which we focus are particular to the transnational bankruptcy context. At first glance, it may seem that the problems that arise when a bankrupt firm has creditors from various countries are no different than those that arise when a bankrupt firm has creditors from different states within the United States. After all, in both cases it is possible that the issue of favoritism toward local creditors may arise.

In the case of a bankrupt firm with creditors from different states within the United States, however, favoritism is unlikely. In such a case, all creditors are from the same country and are, therefore, "local" in the sense that the governing national law applies to all parties. In drafting these national laws, governments will take into account the interests of all domestic parties-which is all parties in the case of a domestic bankruptcy-implying that favoritism is not possible. ${ }^{22}$

In contrast, in the case of a firm with creditors from different countries, individual governments may-and often do-choose a policy of favoritism. In other words, the laws that govern are not intended to serve the interests of all parties affected by the bankruptcy. Governments do not take into account the consequences of their actions on individuals who live in other countries-leading to different policy trade-offs than those faced by governments considering only domestic bankruptcies.

${ }^{21}$ A treaty clearly would be the best solution to the problem discussed in the paper, but for various reasons, attempts at establishing multilateral treaties on the subject have not fared well. For a discussion of the challenges facing attempts at treaty writing, see Thomas $\mathbf{M}$. Gaa, Harmonization of International Bankruptcy Law and Practice: Is It Necessary? Is It Possible? 27 Int'l Law. 881, 903-6 (1993).

${ }^{22}$ We recognize, of course, that domestic laws may not actually be drafted with the interests of all citizens in mind. See, for example, Daniel A. Farber \& Philip P. Frickey, The Jurisprudence of Public Choice, 65 Tex. L. Rev. 873, passim (1989). We abstract from this domestic issue in order to focus more clearly on the fact that national governments do not take account of the interests of those outside their own country. 
At the heart of the difference between domestic and transnational bankruptcies is the fact that national governments take into account the interests of and legislate only with respect to those parties within the country. Within the United States, if bankruptcy were carried out at the state level, and if favoritism toward local (that is, in-state) creditors were present, the problems we identify in the paper would arise with respect to purely domestic bankruptcies that cross state lines. If states could favor in-state creditors, the allocation of investments across states would be distorted.

The paper is organized as follows. In the following section, we briefly examine the U.S. Bankruptcy Code and American case law as they apply to transnational bankruptcies. In Section III we present a simple numerical example in order to establish the intuition underlying the paper. In Section IV we set out the general framework to be used throughout the paper, which will be analyzed for the cases of universalism in Section IVB, unilateral territorialism in Section IVC, and bilateral territorialism in Section IVD. We consider the magnitude of the distortion in Section IVE and the question of private solutions in Section IVF. In Section V we discuss the political economy implications of the analysis.

\section{The Prevailing ApProach - Territorialism}

\section{A. The United States}

Before proceeding with the analysis, it is important to clarify where the law stands on the issue of transnational bankruptcies. While the analysis and conclusions of this paper have more general applicability, the laws of the United States will be used as a concrete example of an existing legal regime. ${ }^{23}$ The laws of Britain and Japan will be considered briefly in Section $\mathrm{II} B$. We focus on the laws of the United States both because the American system is the one with which we are most familiar and because it is generally acknowledged that "American statutory law goes further than the law of any other industrialized nation in authorizing cooperation with foreign insolvency regimes." ${ }^{24}$ The American situation, therefore, can be considered the high-water mark of international cooperation in the area of bankruptcy.

The extraterritorial application of U.S. law is clear. In the eyes of the

${ }^{23}$ For a discussion of foreign rules, see Timothy E. Powers \& Rona R. Mears, Protecting a U.S. Debtor's Assets in International Bankruptcy: A Survey and Proposal for Reciprocity, in 1 International Loan Workouts and Bankruptcies, at 27 (Richard A. Gitlin \& Rona R. Mears eds., 3 vols., 1989).

${ }^{24}$ Douglass G. Boshkoff, Some Gloomy Thoughts concerning Cross-Border Insolvencies, 72 Wash. U. L. Q. 931, 932 (1994). 
United States, the jurisdiction of the bankruptcy court and the estate created by the filing of a bankruptcy proceeding extend to all assets worldwide. ${ }^{25}$ More important, however, is the willingness of the United States to relinquish control over assets located in the United States. The true test of universality is the willingness of courts to turn assets over to the court administering the "main"' bankruptcy proceeding. ${ }^{26}$ We will, therefore, focus on the extent to which American courts permit the turnover of assets to foreign bankruptcy courts.

Refusal to turn assets over to foreign courts will benefit local creditors ex post. This is so for several reasons. ${ }^{27}$ The most obvious reason is the expense of travel-litigating a bankruptcy claim is less expensive if it is done closer to home. Local creditors also have the advantage of being able to attach property within their own country and judicial system-saving on both travel and the cost of learning about a foreign collection system. Local creditors may also have the advantage of being subject to only one bankruptcy proceeding. For example, if bankruptcy proceedings are ongoing in multiple jurisdictions, each with its own stay, a creditor that is governed by all the stays is bound by the strictest. This may put that creditor at a disadvantage relative to a local creditor bound only by a more lenient stay. In addition, the international creditor may, for example, have to file to lift the stay in every relevant jurisdiction in order to get at the assets. ${ }^{28}$

Favoritism is also present in the substantive rules of many jurisdictions, including the United States. For example, as discussed below, among the factors to be weighed by courts in determining whether or not to turn assets over to a foreign representative is "protection of claim holders in the United States against prejudice and inconvenience." ${ }^{29}$ There is also a risk

2511 U.S.C. § 541(a) (1994) creates an estate that extends to all assets "wherever located and by whomever held." This has long been understood to include assets abroad.

${ }^{26}$ Although it may be possible, in principle, to refuse turnover without favoring local creditors, in practice the two are closely related for two reasons. First, it is local creditors and fast-moving multinational creditors who are most likely to react quickly to the troubles of an insolvent firm by seeking a security interest, foreclosing, and so on, leaving them in a better position to litigate the actual bankruptcy. Second, it is, of course, local creditors who are able to object to a turnover order if it is not in their interest. In this sense, they will have the option of keeping the assets in the United States and will use that option only when it is to their advantage.

${ }^{27}$ For an early expression of concern regarding the favoritism shown to local creditors, see Kurt H. Nadelmann, Discrimination in Foreign Bankruptcy Law against Non-domestic Claims, 47 Am. Bankr. L. J. 147, 147 (1973): "When a debtor with assets and creditors in more than one country becomes insolvent, however high the profession of adherence to the principle of equal treatment for all creditors, at some places in some way the local assets land in the hands of local creditors."

${ }^{28}$ See Kraft \& Aranson, supra note 12, at 332-33

2911 U.S.C. \& 304(c)(2). 
of favoritism by the judiciary. It is not unheard of for courts in the United States to favor American creditors over foreign ones. For example, in In re Lineas Areas de Nicaragua, ${ }^{30}$ the bankruptcy court agreed to turn assets over to the Nicaraguan bankruptcy proceeding, but only on the condition that all claims of United States creditors be satisfied first. ${ }^{31}$ Similarly, in In re Cunard" ${ }^{32}$ the Second Circuit stated that "comity would not be granted if it would result in prejudice to United States citizens." ${ }^{33}$ This is, of course, a form of favoritism toward local creditors, as it gives them the benefit of either American or foreign law-whichever is more advantageous.

Transnational bankruptcies are covered by Section 304 of the United States Bankruptcy Code, ${ }^{34}$ introduced in the Bankruptcy Reform Act of $1978 .^{35}$ The statute allows a foreign representative to begin ancillary (that is, secondary) proceedings in the United States by filing a petition with the bankruptcy court. Section 304(b) gives the court the authority to enjoin an action against a debtor where that action relates to property involved in a foreign bankruptcy proceeding, enjoin an action against the property, or enjoin enforcement of a judgment against the debtor with respect to the property. It also permits a court to turn property over to a foreign representative. ${ }^{36}$

In evaluating a petition for ancillary relief, the court is to be guided by (1) "just treatment of all holders of claims," (2) "protection of claim holders in the United States against prejudice and inconvenience,"' (3) "prevention of preferential or fraudulent dispositions of property," (4) "distribution of proceeds ... substantially in accordance with the order prescribed by" American law, (5) comity, and (6) provision of a fresh start. ${ }^{37}$ A local creditor capable of defeating a Section 304 petition by appealing to these factors is essentially given the choice of litigating under the law of the foreign jurisdiction or opposing the Section 304 petition and litigating under American law. In other words, the local creditors will be in a position to choose the law more favorable to themselves. ${ }^{38}$

${ }^{30} 10$ B.R. 790 (S.D. Fla. 1981).

${ }^{31}$ Id. at 791 .

32773 F.2d 452 (2d Cir. 1985).

${ }^{33}$ Id. at 457.

3411 U.S.C. $\$ 304$ (1994).

${ }^{35}$ Bankruptcy Reform Act of 1978, Pub. L. No. 95-598, 92 Stat. 2549.

${ }^{36} 11$ U.S.C. $\$ 304(b)(2)(1994)$.

3711 U.S.C. $\$ 304$ (c) (1994).

${ }^{38}$ The law is, of course, available to all parties to the transaction, but American creditors are much more likely to prefer adjudication in the United States and are more likely to be protected by $\S 304(\mathrm{c})$. For example, they are more likely to be "claim holders in the United States." 
Courts have adopted two general attitudes toward Section 304. One emphasizes comity ${ }^{39}$ and tends to apply Section 304 fairly liberally. The second emphasizes other factors, especially Section 304(c)(2)-(4), and refuses Section 304 petitions more frequently.

The first comprehensive case law discussion of Section 304 came in In re Culmer. ${ }^{40}$ In this case, a Bahamian corporation, BAOL, entered voluntary windup procedures under Bahamian law, and the liquidators subsequently filed a Section 304 petition, seeking the turnover of assets located in the United States to Bahamian courts. ${ }^{41}$

The court pointed out that all of the factors in Section 304(c) have traditionally been used in the consideration of comity. ${ }^{42}$ With this fact in mind, the court enunciated the following standard: "Comity is to be accorded a decision of a foreign court as long as that court is of a competent jurisdiction and as long as the laws and public policy of the forum state are not violated." 43 The court stated that it would look to factors other than comity only "to determine whether the evidence presented as to Bahamian law indicates that its application therein would be wicked, immoral, or violate American law and public policy." ${ }^{44}$ In other words, the court in Culmer appeared willing to grant a Section 304 petition subject only to a narrow public policy exception. In particular, it is not necessary for the applicable law or the rights of the American petitioner to be identical in the two proceedings. ${ }^{45}$

In In re Papeleras Reunidas, S.A., ${ }^{46}$ the court took a different approach to Section 304 petitions. Rather than use the factors other than comity to determine if the foreign law was "wicked, immoral, or violate[s] American

3911 U.S.C. $\& 304(\mathrm{c})(5)$. The classic definition of comity is provided in Hilton v. Guyot, 159 U.S. 113 (1895): " 'Comity,' in the legal sense is neither a matter of absolute obligation, on the one hand, nor of mere courtesy and good will, upon the other. But it is the recognition that one nation allows within its territory to the legislative, executive or judicial acts of another nation, having due regard both to international duty and convenience, and to the rights of its own citizens or of other persons who are under the protection of its laws." Id. at 16364.

${ }^{40} 25$ B.R. 621 (Bankr. S.D.N.Y. 1982).

${ }^{41} \mathrm{Id}$. at $623-25$.

${ }^{42}$ Id. at 629.

${ }^{43}$ Id. (citing Hilton v. Guyot, 159 U.S. 113, 202-3 (1895)).

44 Id. (quoting Cornfeld v. Investors Overseas Services, Ltd., 471 F. Supp. 1255 (S.D.N.Y. 1979), which in turn quotes Intercontinental Hotels Corp. v. Golden, 15 N.Y.2d 9, 13 (1964)).

${ }^{45}$ Other cases that emphasize comity in this way include Metzeler v. Bouchard Transportation Co. (In re Uni-Petrol Geselleschaft fuer Mineralolprudukte), 78 B.R. 674, 677 (Bankr. S.D.N.Y. 1987); and In re Gee, 53 B.R. 891 (Bankr. S.D.N.Y. 1985).

4692 B.R. 584 (Bankr. E.D.N.Y. 1988). 
law and public policy," 47 the court chose to "equally consider all of the variables of Section 304(c) in determining the appropriate relief." 48 The court therefore considered each of the Section 304(c) factors individually and conducted an informal balancing test. ${ }^{49}$ Using this higher standard, Papeleras rejected the Section 304 petition. $^{50}$

For further evidence of the conflict between these different methods of interpretation, compare Culmer ${ }^{51}$ and In re Toga ${ }^{52}$ In Culmer, the court states in dicta that "it is well-settled that the liquidation laws of Canada, which are virtually the same as those of the Bahamas, are to be given effect under principles of comity." 53 In Toga, which was decided only a year after Culmer, the court refused to turn over funds to Canadian courts. Rather, it sought to protect an American corporation that was a lien creditor under American law but that "would most likely be considered an "ordinary creditor' "' under Canadian law. ${ }^{54}$ On the basis of this difference in substantive law, the court ruled that Canadian law is not "substantially in accordance with the order prescribed by the title." 55 Even if it is true, as suggested in the decision, that the American corporation in Toga would be treated differently under Canadian law, it cannot be said that Canadian law is "inherently wicked, immoral, or violates American law and policy" as required by Culmer. ${ }^{56}$

One possible reason for the inconsistency in the application of Section 304 may be a poor understanding of the impact of the law. To further our understanding of the law, this paper focuses on its ex ante capital allocation effects. A more careful examination of the impact of territoriality demonstrates that it is, indeed, harmful, and efforts are needed to move us toward a more universalist regime.

Finally, before proceeding to demonstrate the key results of the paper through a simple example, we point out that a firm cannot easily avoid the inefficiencies that we will identify. We will discuss this fact at greater

\footnotetext{
${ }^{47}$ In re Culmer, 25 B.R. at 629.

${ }^{48}$ In re Papeleras Reunidas, S.A., 92 B.R. at 590.

${ }^{49} I d$. at 589-95. 165 (Bankr. E.D. Mich. 1983).

5125 B.R. 621 (Bankr. S.D.N.Y. 1982).

5228 B.R. 165 (Bankr. E.D. Mich. 1983).

${ }^{53}$ In re Culmer, 25 B.R. 621 , at 631.

${ }^{54}$ In re Toga, 28 B.R. 165, at 168.

s5 Id. at 169.

${ }^{56}$ In re Culmer, 25 B.R. 621 , at 629.
}

${ }^{50}$ Other cases that do not emphasize comity include Interpool Ltd. v. Certain Freights of M/V Venture Star, 102 B.R. 373 (Bankr. D.N.J. 1988), and In re Toga Mfg. Ltd, 28 B.R. 
length later in the paper, ${ }^{57}$ so for the moment we simply point out that it is not possible for a firm to opt out of the bankruptcy laws. ${ }^{58}$

\section{B. Other Countries}

Although this paper focuses on the response of the United States to the problem of transnational bankruptcies, the analysis below is not specific to the American regime. Our conclusions apply equally to any regime choosing between a territorialist and universalist approach. Although it is beyond the scope of this paper to provide a detailed discussion of the jurisdiction of bankruptcy laws around the world, this section will briefly mention the approach taken in two other countries-Britain and Japan.

The United Kingdom deals with the problems of transnational bankruptcies through Section 426 of the Insolvency Act of 1986 . The Insolvency Act provides for international cooperation by British courts with any other court that has jurisdiction over an insolvency proceeding in any "relevant country or territory." 59 A country becomes a relevant country or territory when it is designated as such by Ministerial Order. The current list of relevant countries is limited to present and former colonies such as the Cayman Islands and Bermuda, and to Canada, Australia, New Zealand, and the Republic of Ireland. ${ }^{60}$ A request by a court in a relevant country or territory allows a British court to apply the insolvency law of either country to the issues at hand: thus a potentially far-ranging authorization is conferred upon the court to devise an appropriate response to a request for international assistance by combining a regard for the rules of private international law together with its mandate to apply either domestic insolvency law or the insolvency law of the jurisdiction from which the request has been received. ${ }^{61}$ In the case of a country that is not a "relevant country or territory," including the United States, there are no explicit statutory provisions

37 See Section IVF infra.

58 Some commentators have suggested that a firm should be allowed, at the time of its founding, to select the bankruptcy law that applies to it. See Robert K. Rasmussen, Debtor's Choice: A Menu Approach to Corporate Reorganization, 71 Tex. L. Rev. 51 (1992); Barry E. Adler, Financial and Political Theories of American Corporate Bankruptcy, 45 Stan. L. Rev. 311 (1993); Alan Schwartz, Bankruptcy Workouts and Debt Contracts, 36 J. Law \& Econ. 595 (1993).

59 Insolvency Act of $1986 \S 426(4)$.

${ }^{60}$ See Leonard Hoffmann, Cross-Border Insolvency: A British Perspective, 64 Fordham L. Rev. 2507, 2511-12 (1996).

${ }^{61}$ Ian Fletcher, Cross-Border Cooperation in Cases of International Insolvency: Some Recent Trends Compared, 6/7 Tul. Civ. L. F. 171, 183-83 (1991/1992). 
governing cooperation. Such cases must rely on ad hoc cooperation arrangements, which have not generally proven to be a satisfactory solution. ${ }^{62}$

Japan continues to have an extremely territorial law with respect to transnational insolvencies. ${ }^{63}$ In particular, the law contains the following provisions:

1. A bankruptcy adjudged in Japan shall be effective with respect to only the bankrupt's properties existing in Japan.

2. A bankruptcy adjudged in a foreign country shall not be effective with respect to properties existing in Japan. ${ }^{64}$

Although some small efforts have been made to allow some limited degree of universalism, the laws of Japan remain very territorialist, as the above legislation indicates. ${ }^{65}$

A review of the laws of other countries confirms what is suggested by the laws of the United States, Britain, and Japan. Although there are some limited instances of cooperation, the dominant approach to transnational bankruptcies remains territorial, and the laws of the United States can fairly be characterized as the most universalist among the western nations.

\section{A Simple ExAmple}

The basic intuition of the model can be developed through a simple numerical example. Imagine two countries, say the United States and Britain, and suppose that the United States has a territorialist regime in place, while Britain has a universalist regime. Finally, assume the existence of a firm with $\$ 100$ million of existing British debt in year 0 and an interest rate of $r{ }^{66}$ The creditors to whom the firm is indebted will be referred to as the "old" or $t=0$ creditors. The domicile of the firm is not important for our purposes-all that matters is the location of its $t=0$ creditors. It will be

62 For two famous examples of international insolvencies involving both the United States and Britain, see Felixstowe Dock \& Railway Co. v. U.S. Lines, Inc., [1989] Q.B. 360, and the Maxwell Communications Corporation bankruptcy. For a discussion of these cases, see Hoffmann, supra note 60, at 2512-14.

${ }^{63}$ See Shoichi Tagashira, Intraterritorial Effects of Foreign Insolvency Proceedings: An Analysis of "Ancillary" Proceedings in the United States and Japan, 29 Tex. Int'l L. J. 1, passim (1994).

${ }^{64}$ Id. at 7 n.33.

${ }^{65}$ Id. at 6-9.

66 The firm also has assets that we can assume are located in Britain. 
demonstrated that the decisions of value-maximizing firms with existing British debt will be distorted in favor of investing in the United States.

Suppose that the firm wishes to make an investment. The firm can invest in either the United States or Britain and can also borrow from lenders in either country. In year 1, the firm invests in one of the two countries and, in year 2, it borrows $\$ 100$ million from either British or American creditors. This $t=2$ borrowing can take place for any reason. It could be to complete the project started at $t=1$, it could be for an unrelated project, or it could be for any other reason. We need only assume that the borrowing takes place after the investment decision at $t=1$. These creditors will be referred to as the "new" or $t=2$ creditors. The firm then invests that $\$ 100$ million in either the United States or Britain.

The firm's business, however, is not without risk. In year 3, the investment "'matures," and if it is successful (as is assumed to occur with probability 0.8 ), the firm receives $\$ 215$ million (before paying its debts) if it chose to invest in the United States and \$225 million if it invested in Britain. If, however, the investment is unsuccessful, the firm recovers only $\$ 100$ million and, being unable to pay its creditors, must file for bankruptcy. It is assumed that the payoff to the firm is physically located where the $t=1$ investment took place. Imagine that production and, therefore, the firm's output (which represents its payoff) is located where the $t=1$ investment takes place. After year 3, the firm's assets are assumed to have no value. ${ }^{67}$

If both countries have bankruptcy laws that treat all creditors equally, then the old and new creditors will each get $\$ 50$ million in the event of bankruptcy. Knowing that creditors will each get a pro rata share in the event of bankruptcy, both American and British lenders will be prepared to offer the firm the same interest rate at $t=2{ }^{68}$ The firm will be indifferent between creditors, and the investment decision will depend entirely on the return to the investment, causing the firm to choose to invest in Britain since it can earn $\$ 225$ million there, and only $\$ 215$ million in America. This is the efficient outcome because the assets are invested where they will be the most productive.

Suppose, however, that the United States has laws that favor American creditors in the event of bankruptcy. For clarity of presentation, we assume

${ }^{67}$ Alternatively, one can imagine that there is also a stock of senior debt in Britain that accounts for the assets located there. In this case, the figures given in this example represent unsecured assets only.

${ }^{68}$ Capital markets are assumed to be competitive, so lenders always receive the world rate in expectation. In order to arrive at the interest rate figures in this example, we have assumed an underlying world interest rate of 4.8 percent. In the universalism case, both British and American creditors would demand 18.5 percent at $t=2$ to compensate them for the risk. 
that in the event of bankruptcy the law requires that local (that is, American) creditors be paid in full before any of the assets located in the United States can be used to satisfy the claims of foreign creditors. ${ }^{69}$ If the firm borrows and invests in the United States, and if the firm goes bankrupt, the American creditor will be paid the full $\$ 100$ million, while the $t=0$ (British) creditor will receive nothing. In other words, the American creditor's return in the event of bankruptcy is higher than it is under the universalist case above. Since we have assumed competitive credit markets, the lender must receive exactly the world rate of interest in expectation, and a higher payoff in bankruptcy implies that the contractual interest rate will be lower. The American creditor will, therefore, offer a rate of interest that is below the rate demanded under universalism. In our example, the American creditor will demand a rate of 6 percent. $^{70}$

If the firm invests in universalist Britain at $t=1$, creditors will all receive a pro rata share of assets in the event of bankruptcy. Prospective $t=$ 2 creditors from Britain and the United States, therefore, will offer the same interest rate as under universalism, 18.5 percent.

In choosing its investment location, the firm will take account of the effect of its choice on the available interest rate. It will invest in the country in which the expected return to capital is highest, net of interest payments. In this example, the firm will invest in the United States, where it can earn $\$ 215$ million on the investment and pay only $\$ 6+r$ million in interest leaving it with a $\$ 9-r$ million net return. In Britain, on the other hand, the firm would receive $\$ 225$ million from the investment, but would have to pay $\$ 18.5+r$ million in interest charges, leaving it with a $\$ 6.5-r$ million net return on the borrowed capital. ${ }^{71}$

The territorialist legislation, therefore, has led to a suboptimal investment decision. Instead of earning $\$ 25$ million in Britain, the borrowed assets earn only $\$ 15$ million in the United States. What the firm perceives as an interest rate "savings" due to investment in America is actually a transfer from the old British creditor to the firm. Because we assume rational expectations on the part of the original creditors (and all other actors), it is the firm that will ultimately pay the cost generated by the territorialist legislation. The firm, therefore, would be better off if it could "opt out" of the territorialist legislation and commit to a single forum for adjudication.

${ }^{69}$ This is, of course, an extreme version of territoriality. It is used in order to make the presentation clearer. More moderate territorialist measures will yield the same qualitative results.

${ }^{70}$ If the firm invests in the United States but borrows from Britain, creditors will demand the same rate as they would under universalism, 18.5 percent.

${ }^{71}$ These figures represent the return to the firm in the good state. In the bad state, the firm receives nothing regardless of the location decision. 
The rest of this paper will develop the intuitions of this example in a more general framework and with more rigorous attention to the assumptions involved.

\section{THE MODEL}

\section{A. Framework of Analysis}

In order to explore the implications of favoring local creditors, we use a two-period, two-country model. The countries are labeled $A$ and $B$ (and can be thought of as America and Britain). The firm begins with an exogenous debt structure, which, for simplicity, is assumed to consist of a single creditor in one of the two countries. The firm may also have some initial assets. ${ }^{72}$ It is assumed throughout that all agents are risk neutral and that capital markets are competitive so that lenders receive exactly the risk-adjusted world rate of interest in expectation. The initial creditor will accordingly be assumed to have chosen an interest rate such that, at $t=0$, she receives the world rate in expectation. This is equivalent to allowing another period $(t$ $=0$ ) in the model in which the firm borrows from this initial creditor. ${ }^{73}$ We denote the initial debt $D^{0}$ and refer to the initial creditor as the $t=0$ creditor. ${ }^{74}$

While allowing endogenous determination of initial debt is perhaps a more satisfying approach from a modeling perspective, it is probably more realistic to assume an exogenous determination of that debt. Most multinational corporations begin as purely domestic firms with purely domestic creditors. A small percentage of these firms eventually become multinational enterprises. By the time a firm becomes a multinational corporation, it is likely to be a mature corporation with a debt structure dictated by its domestic development. ${ }^{75}$ By way of example, consider the automobile industry in the United States. For many years following the Second World War, the United States was the dominant manufacturer of automobiles. In time, other countries began to compete with the United States, and by the mid-1970s foreign producers began to consider the establishment of manu-

${ }^{72}$ These initial assets are assumed to have no value at $t=3$. If they had some value at $t$ $=3$, we could take into account the rules governing the distribution of these assets in the event of bankruptcy.

${ }^{73}$ While it is true that the $t=0$ creditor can be "stolen from" at $t=2$, she will take this into account when the initial loan is made. The $t=0$ creditor, therefore, will demand an interest rate such that she receives the world interest rate in expectation given the knowledge that the firm will try to take advantage of her at $t=2$.

${ }^{74}$ Throughout the paper, superscripts will be used to denote time and subscripts will be used to identify countries.

${ }^{75}$ See Richard E. Caves, Multinational Enterprise and Economic Analysis (2d ed. 1996). 
facturing operations in the United States. By the time these foreign firms undertook foreign investments in the United States, they were already successful global companies. For example, Volkswagen, the first foreign firm to launch a major car project in the United States, did not begin its investment until $1976 .^{76}$ Other major car manufacturers also arrived long after they were established companies with existing obligations-Renault in 1979 , Honda in 1980, Volvo in 1981, and Toyota in 1983."

Since there is a cost associated with borrowing abroad that does not exist when one borrows at home-where one is familiar with local institutions and legal requirements-it is rational for domestic firms to simply borrow locally, despite the distortion that this paper describes. For existing multinational enterprises, the story is similar. Before knowing what form an investment opportunity will take, a firm cannot hope to invest optimally to avoid future distortions when such an opportunity arises. As a result, firms engaging in foreign investment will often have existing debt obligations that are determined by the firm's past needs rather than its current investment plans.

At $t=1$, the firm has an investment opportunity that it can pursue in either country $A$ or country $B$. There are at least two different ways to think of the firm's behavior. For example, many American firms have invested in Mexico in recent years in order to take advantage of the provisions of NAFTA. Manufacturing takes place in Mexico, and the product is then sold in the United States. Firms making such decisions may have the option of choosing an investment location from among several possible countries. ${ }^{78}$ Alternatively, the firm may be trying to get better access to its marketthis explains a great deal of foreign investment into the United States, including the automobile industry as mentioned above. In this case, it is not a choice among several potential host countries, but rather a choice between the firm's home country and a single potential host. The analysis in this paper applies to both types of investment decisions.

In order to pursue its investment opportunity, the firm chooses the location of the investment project. This choice may take many forms. It may involve the actual construction of a plant, the signing of contracts committing the firm to certain activities within the country, or any other actions that commit the firm to the chosen country. The choice between the two countries will depend in part on whether the project would be more effec-

${ }^{76}$ See Neil Hood \& Stephen Young, Foreign Direct Investment in the U.S. Automobile Industry, in 5 Research in International Business \& Finance 175 (H. Peter Gray ed., 5 vols., 1986).

77 Id. at $175-83$

${ }^{78}$ Many countries have sought to attract such investment by making themselves more appealing to potential investors through tax-free zones, contractual arrangements with investors, bilateral investment treaties, and so on. 


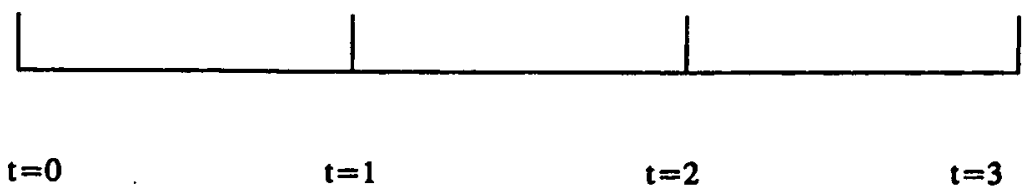

Initial debt Initial investment Borrow Output realized

FIGURE 1.-Timing

tive in country $A$ or $B$, which depends, in turn, on the state of nature. We define two states of nature, $\theta_{A}, \theta_{B}$. If the state of nature is $\theta_{A}$, the investment project would be more effective if placed in country $A$. If the state of nature is $\theta_{B}$, country $B$ provides the more effective location for the project. Without loss of generality, we assume that the probability of each state is 0.5 . In addition, we make the standard assumption that the state of nature is not verifiable to a court, and it is thus not possible to write contracts contingent upon it.

At $t=2$, the firm borrows an amount, $D^{2}$, from either a lender in country $A$ or a lender in country $B .^{79}$ Without loss of generality, we assume that the firm will do all of its borrowing from the same lender.$^{80}$ The nature of the investment is assumed to be such that all investment must take place in a single country. ${ }^{81}$

At $t=3$ output is realized. If the project goes badly, as occurs with probability $1-\rho$, the firm cannot meet its credit obligations and goes bankrupt. The remaining assets, $W$, are divided according to the law of the country in which the investment took place. Below, we will consider alternative rules governing the division of $W$. On the other hand, if the project goes well, as occurs with probability $\rho$, the firm is able to pay off its debts and earn a profit. The firm is assumed to earn a rate of return that is higher by an amount $G$ if the investment is located in the more profitable country, as determined by the state of nature, $\theta_{i}, i=A, B$. The variable $G$ is defined as a gross rate of return, calculated before interest payments (see Figure 1).

79 The $t=2$ creditor and the $t=0$ creditor are assumed to be the only creditors. Thus, all creditors are voluntary and adjusting creditors.

${ }^{80}$ Only in some special cases will the firm be indifferent to the proportion borrowed from each lender at $t=2$. In all other cases, the firm will choose to do all of its borrowing from the lender offering the lower rate. The firm will never prefer to borrow from more than one lender.

${ }^{81}$ This assumption is not required, but it simplifies the model. 
We approach the question of capital allocation from an efficiency perspective. ${ }^{82}$ From that perspective, it is desirable that firm decisions regarding the allocation of capital be made based on the total return to capital. Differences between the total return to capital and the return realized by the firm have the potential to generate inefficiencies.

We first consider the case in which neither country has territorialist laws in place-that is, both countries treat all creditors equally, regardless of nationality. We demonstrate that the first-best outcome is attainable under universalism. We will then consider the case in which only one country is territorialist, demonstrating that investment may be influenced by the territorialist laws. Finally, we examine the case in which both countries are territorialist. We demonstrate that territorialist measures, when adopted multilaterally, lead to a distortion of the investment decision.

\section{B. Universalism (First Best)}

Under a universalist regime, the firm makes its investment decision based only on the expected return of the project. Since all creditors are treated equally in bankruptcy, they all offer the same rate of interest at $t=2$, regardless of the location of the investment. The firm will be indifferent between creditors and will simply invest in the country in which productivity will be highest. The firm, therefore, invests in country $A$ if the state of nature is $\theta_{A}$ and in $B$ if the state of nature is $\theta_{B}$. This is the first-best or efficient outcome.

We can express this result formally in terms of the participation constraint facing lenders. In a universalist world, the participation constraint for all lenders is

$$
\rho R_{i}+(1-\rho) \frac{W}{D^{0}+D^{2}}=R^{*} \quad i=A, B,
$$

where $R_{i}$ represents the contracted interest rate between the firm and the lender in country $i\{i=A, B\} ; R^{*}$ represents the exogenous world interest rate; $D^{j}$ represents the debt acquired at $t=j\{j=0,2\}$; and $W$ represents the dollar value of assets remaining for division among the creditors in the event of bankruptcy. ${ }^{83}$

Equation (1) states that the lender must receive, in expectation, a return equal to the world rate of interest. The first term in equation (1) represents the payoff to the lender in the good state multiplied by $\rho$, the probability

${ }^{82}$ Given that capital markets are efficient and all creditors get the world rate in expectation, the perspective of efficiency is equivalent to an ex ante perspective.

${ }^{83}$ Interest rates are expressed as gross rates. 
of being in that state. The second term represents the payoff to the lender in the bad state, in which the firm goes bankrupt, multiplied by $1-\rho$, the likelihood of such an outcome. In the event of bankruptcy, each creditor receives a pro rata share of the assets. The assets are represented by $W$, while the debt is equal to $D^{0}+D^{2}$. For each dollar invested, the creditor therefore receives a gross return of $W /\left(D^{0}+D^{2}\right)$.

\section{Unilateral Territoriality}

We begin the analysis of territorial laws with the case of unilateral territorialism. It is assumed, without loss of generality, that country $A$ adopts a territorialist regime while country $B$ maintains a universalist regime. Under $A$ 's territorialist legislation, foreign creditors are paid only after local creditors are paid in full. With respect to assets located in $A$, the creditors from $B$ essentially become junior creditors relative to those from $A$.

The main result we show in this section is that unilateral territoriality leads to a distortion of the investment decisions made by firms whose initial debt is from $B$. This distortion will favor investment in the territorialist country, $A$. While this may be desirable from the point of view of the territorialist state, it is inefficient from a global point of view and harmful to the debtor.

A secondary result concerns lending patterns. It is shown that unilateral territoriality leads to increased borrowing from creditors in the territorialist state. Because territorial rules protect local creditors ex post, those creditors will, all else being equal, offer a lower interest rate ex ante, and firms are more likely to choose to borrow from them. In a model with competitive capital markets, this has no welfare effects, but in a model with rents to lending, territoriality would, in fact, benefit local creditors.

To solve the model, we will proceed backward, starting with $t=3$. At $t$ $=3$, with probability $\rho$ the investment project is successful and the firm is able to pay it debts. With probability $1-\rho$ the firm gets $W$, which is defined as the dollar value of assets to be distributed in bankruptcy. ${ }^{84}$ In order to make the presentation clearer, we assume that $W<D^{2}$. Under this assumption, if the new creditor is "senior" to the old creditor, the former receives all the assets and the latter receives nothing. This assumption is not essential-the same results can be obtained without it but at a cost of greater complexity. ${ }^{85}$

${ }^{84}$ In principle, $W$ could take on a different value, depending on the country in which the firm invests. Assuming that it is the same in the two countries keeps the model simpler without affecting the results.

${ }^{85}$ The critical part of the analysis is that the distribution of assets favors one creditor over another. When $W>D^{2}$, this favoritism still exists but the actual derivation of the distortion is made more complex. 
Consider first the effect of territorialism in $A$ on the interest rates offered by creditors when the firm's existing debt is from $B$. If the firm decides to invest and borrow in $A$, the new creditor will be treated as senior relative to the existing creditor in $B$. The new creditor, therefore, will be willing to offer an interest rate discount. We can write the lending constraint for the lender from $A$ as

$$
\rho R_{A}+(1-\rho) \frac{W}{D^{2}}=R^{*} \quad i=A, B
$$

Because the creditor from $A$ is given priority in the distribution of assets, her return in the event of bankruptcy is higher than it is in the universalist case. Comparing equation (1) and equation (2), it is clear that the interest rate, $R_{A}$, required to satisfy the constraint is lower in equation (2) than in equation (1)-this is the source of the interest rate discount.

If the firm chooses to borrow from $B$ and invest in $A$, the new creditor receives a pro rata share in bankruptcy, just as she would in a universalist world. In order to secure the world rate of return, therefore, the creditor will demand the same interest rate as she would under universalism-equation (1) applies. From the firm's point of view, it is obviously preferable to borrow from the creditor offering the lowest rate of interest, so a creditor with initial debt in $B$, planning to invest in $A$, will borrow from $A$.

Note that the above distortion of the interest rate only occurs when the initial debt is from the universalist country and the investment is to be in the territorialist country. If the firm planned to invest in $B$, the source of debt would not matter because $B$ has a universalist regime, meaning that the assets would be distributed pro rata to all creditors. Similarly, if the initial debt were held by creditors in $A$, and if the investment were to be made in $A$, the firm could secure debt at the universalist rate from creditors in $A$. Potential creditors in $B$ would demand an interest rate premium to account for the fact that they would be junior relative to the existing creditors. The firm, of course, would always borrow from creditors in $A$ in order to avoid the higher rate demanded by those in $B$-leaving the firm with the same rate as under a universalist regime.

In summary, if the assets are to be invested in universalist $B$, creditors from both $A$ and $B$ offer a rate of interest equal to the universalist rate given by equation (1). If the assets are to be located in $A$, creditors from $A$ offer a lower interest rate than those from $B$. In this second case, if initial debt is owed to creditors from $A, t=2$ creditors from $A$ offer the universalist rate and creditors in $B$ demand an interest rate premium. If, however, the initial debt is owed to a creditor in $B$, potential $t=2$ creditors in $B$ demand the universalist rate of equation (1) and creditors from $A$ offer an interest 
TABLE 1

INTEREST RATES UNDER TERRITORIALITY

\begin{tabular}{lcc}
\hline \hline$t=0$ Creditor & $\begin{array}{c}\text { Location of } \\
\text { Assets }\end{array}$ & $\begin{array}{c}t=0 \\
\text { Interest Rate }\end{array}$ \\
\hline$A$ or $B$ & $B$ & $R_{A}=R_{B}=R_{N P}$ \\
$A$ & $A$ & $R_{N P}=R_{A}<R_{B}$ \\
$B$ & $A$ & $R_{A}<R_{B}=R_{N P}$ \\
\hline
\end{tabular}

NoTE. $-R_{N P}$ represents the universalist rate of interest given by equation (1).

discount given by equation (2). These results are summarized in Table 1 . These interest rate distortions ensure that whenever the assets are to be located in $A$, the firm will borrow from a creditor in $A$. When the assets are to be placed in $B$, the firm is indifferent to the choice of creditor.

Having considered the borrowing decision, given the investment decision, we now consider how the firm chooses the location of its assets. Under the first-best universalist regime, the only factor influencing the firm's investment decision is the state of nature, $\theta_{i}, i=A, B$. When country $A$ is territorialist, however, the firm must consider more than just these returns. If the firm's $t=0$ debt is from $B$, and it plans to invest in $A$, it faces the interest rate given by equation (2); otherwise, it faces the interest rate given by equation (1). If the firm does invest in $A$ (assuming that it has existing debt in $B$ ), it can capture for itself the difference between these two interest rates.

The firm, of course, is interested in its return after interest payments, so it will take into account the difference in interest rates. Letting $\Delta R$ represent the difference between the interest rate $R_{B}$ offered by creditors in $B$ (as given by equation (1)) and the interest rate $R_{A}$ offered by creditors in $A$ (given by equation (2)), and recalling that $G$ represents the difference between the rate of return in the more profitable country and the return in the less profitable country, the firm will invest in $A$ if and only if

$$
\begin{aligned}
& G>-\Delta R \quad \text { if state of nature is } \theta_{A}, \\
& G<\Delta R \quad \text { if state of nature is } \theta_{B} .
\end{aligned}
$$

In other words, the firm invests in $A$ if the return to the investment plus the interest rate savings exceed the return in $B$. If $\Delta R \neq 0$, then there will be values of $G$ for which the firm will invest in the country with the lower return to capital in order to take advantage of the interest rate savings. In other words, for certain values of $G$ and $R$, capital will be allocated suboptimally as a direct result of the territorialism. 
The value of $\Delta R$ can be calculated by subtracting equation (2) from equation (1). The result is ${ }^{86}$

$$
\Delta R=\frac{(1-\rho) W}{\rho}\left[\frac{D^{0}}{D^{2}\left(D^{0}+D^{2}\right)}\right] \geq 0 .
$$

For any positive stock of initial debt, $D^{0}$, it is clear that there is a distortion $(\Delta R \neq 0)$ that will encourage the firm to invest in $A$ and borrow from creditors in $A$, even if that country does not offer the greatest return to capital. The territorialism of $A$ will induce some firms to invest in $A$, despite the fact that it would be more efficient for them to invest in $B$.

By assuming that creditors receive the world rate in expectation, we have assumed that the lower return due to the distortion of investment decisions is borne by the firm rather than the creditors. The firm achieves a lower interest rate at $t=2$ but will have paid a higher rate at $t=0$. The interest rate discount in the territorialist country and the premium in the other country will leave the firm paying the world rate in expectation overall. It is the firm that receives a lower return when it invests suboptimally. This implies that the firm would be better off at $t=0$ under a universalist regime.

Firms with initial debt in $A$ are not affected by the distortion. Firms with initial debt in $B$, however, do face the distortion. In some instances, these latter firms will invest in $A$ despite the fact that their capital would be more productive in $B$. The territoriality of $A$, therefore, will attract additional capital and, with it, an increased demand for borrowing from creditors in $A$.

Note that an implication of our model is that when domestic companies from $B$ invest in territorialist $A$, they will tend to create some borrowing from creditors in $A$. This implication is consistent with, and can help to explain, the empirical evidence according to which firms prefer to finance projects in foreign countries (which are commonly territorialist) with borrowing from within the country in which they are investing. ${ }^{87}$ The explanation commonly given for such local finance is risk aversion on the part of the multinational and reduction of foreign exchange risk. The analysis of this paper suggests another factor that might lead to such local finance-a factor that is present even if risk aversion is not a factor (which might well

${ }^{86}$ We know that $\Delta R$ is positive because we have assumed that $A$ is territorialist while $B$ is not. If $B$ is territorialist and $A$ is not, $\Delta R$ will be negative.

${ }^{87}$ See Caves, supra note 75; J. N. Behrman, Foreign Associates and Their Financing, U.S. Private and Government Investment Abroad 1995-1998 (Raymond F. Mikesell ed. 1962) (concluding from survey evidence that most American multinationals attempt to minimize the dollar equity invested abroad, preferring to borrow locally); Michael Z. Brooke \& H. Lee Remmers, The Strategy of Multinational Enterprise: Organisation and Finance 182, 195 (1970); Stacey M. Robbins \& Robert B. Stobaugh, Money in the Multinational Enterprise: A Study of Financial Policy, ch. 4 (1973). 
be the case for large multinationals making a limited investment in a foreign country).

Finally, note that the model implies that unilateral territoriality is a form of subsidy to encourage domestic firms from $B$ to become multinationals by investing in $A$. Imagine a large number of $B$ 's local firms borrowing at $t=0$ and assume that only a small proportion of those will become multinationals. Finally, suppose that while the probability of becoming a multinational is common knowledge, neither the lender nor the borrowers at $t=$ 0 can distinguish between those that will become multinationals and those that will not. Those that do become multinationals will make their creditors in $B$ junior to their $t=2$ creditors in $A$. To be compensated for this loss, $t$ $=0$ lenders will demand a higher rate of interest from all firms - such that they receive the world rate in expectation. This interest rate will be less than the rate that would be charged to a firm that the creditor knew would later invest abroad since most borrowers will never do so. Those that do become multinationals, therefore, will benefit from the lower interest rate offered by lenders in $A$, while those that do not will suffer due to the higher interest rate in $B$ caused by the risk of firms becoming multinationals. Thus, territoriality creates a subsidy for firms that go multinational, paid in part by those in $B$ that do not.

\section{Both Countries Territorialist}

We now examine the case in which both countries favor their own creditors in the event of bankruptcy through laws that require local creditors to be paid in full before foreign creditors receive any compensation. We will show that a firm with debt in one country will have its investment decision distorted in favor of the other country.

Consider, without loss of generality, the case in which a firm has initial debt in $B{ }^{88}$ The analysis of the distortion in favor of investment in $A$ is essentially the same as shown in Section IVC. The distortion is not affected by whether $B$ is territorialist or not. To see that this is true, consider a firm that borrows new debt from $A$ and invests in $A$. Since $A$ is territorialist, and the existing debt is held in $B$, the new creditor will be senior relative to the old creditor. This seniority will be reflected in the interest rate as shown in Section IVC.

If the firm invests in $B$ and $B$ is universalist, Section IVC demonstrates that the new debt will be treated as equal in seniority to the old debt, regard-

${ }^{88}$ Because the model is symmetric, the case in which the debt is in $A$ is identical to the case we present. The analogous results can be obtained by reversing the country names in the analysis that follows. 
less of the location of the new creditor. If, on the other hand, $B$ is territorialist, potential creditors from $A$ will demand an interest rate premium to account for the fact that they will be junior in bankruptcy. Creditors in $B$, however, will not demand such a premium, so the firm will borrow from a creditor in $B$. Since all creditors are then from $B$, they will all be treated equally, and the new credit will be offered at the universalist rate (which is higher than the discount offered by creditors in $A$ if the firm invests in $A$ ).

The example above demonstrates that for firms with existing debt from a creditor in $B$, territorialism by $A$ will distort investment in favor of $A$, just as it did in the unilateral territorialism case. Neither the existence nor the magnitude of the distortion depends on whether $B$ is territorialist. Territorialism in $B$ simply means that firms with existing debt in $A$ would also have their investment decisions distorted.

Territorialism by a given country, therefore, distorts the decision of firms that have debt from another country. This distortion is generated by the ability of the new creditor to divert some of the risk of lending to the existing creditors. In the unilateral territorialism case, only the decisions of firms with debt in the universalist country are distorted. In contrast, in the bilateral territorialism case, all firms are subject to the distortion.

Note that the bilateral territorialism case has the same implication as the unilateral case considered in the preceding section for multinationals' use of local finance. It also implies that when multinationals invest in a country that is territorialist (as countries generally are), they will tend to use local borrowing. Thus, the analysis of the bilateral case is also consistent with and can help to shed light on the evidence noted earlier concerning the extensive use that multinationals make of local financing.

Finally, note that the bilateral territorialism case is different from the unilateral case in one important respect. When both countries are territorialist, it is not possible for the firm to avoid the distortion through careful choice of its $t=0$ creditor unless it can anticipate its future investment opportunities. If the future is uncertain (even if the probability distribution from which future opportunities will be drawn is known), the distortion will remain.

\section{E. The Magnitude of the Distortion}

We now consider the effect of each of the variables on the magnitude of the distortion. ${ }^{89}$ By differentiating equation (4) it is straightforward to show the results in Table 2 .

An increase in $D^{0}$, the initial debt, will increase the distortion because it

${ }^{89}$ For simplicity (and brevity), we concentrate on the bilateral case only. 
TABLE 2

Magnitude OF THE Distortion

\begin{tabular}{lc}
\hline \hline Variable & $\begin{array}{c}\text { Marginal Effect on the } \\
\text { Absolute Value of } \Delta R\end{array}$ \\
\hline$D^{0}$ & + \\
$D^{2}$ & - \\
$\rho$ & - \\
\hline
\end{tabular}

decreases the pro rata share available to the $t=2$ creditor if both creditors are from the same country. In other words, when the firm is confronted with foreign investment opportunities and is holding domestic debt, the distortion is greater when it already has large domestic debt. This result is intuitive: the greater the domestic debt, all else equal, the greater is the local creditors' pro rata share of the assets. Territorialism allows the new foreign creditor to capture these assets in exchange for a lower interest rate. As the amount at stake increases, the interest rate discount grows, generating a larger distortion.

Conversely, greater $t=2$ borrowing $\left(D^{2}\right)$ reduces the distortion because it entitles the lender to a larger pro rata share of the proceeds. All else equal, if a firm with domestic debt borrows a larger sum at $t=2$ and borrows it domestically, the $t=2$ creditor will receive a larger share of the assets in bankruptcy. Foreign creditors will, therefore, be able to offer a relatively small interest rate discount. The advantage of having senior status is reduced as the size of the new debt increases.

Finally, an increase in $\rho$, the investment's probability of success (that is, a reduced probability of bankruptcy), lowers the distortion because the lender is paid in full with greater frequency. The "senior" creditor offers a smaller interest rate discount and the "junior" creditor requires a lower interest rate premium in order to receive the world rate in expectation.

\section{F. Can Ex Ante Private Action Eliminate the Distortion?}

The analysis so far has demonstrated that territorialism produces distorted investment decisions. As we discuss later ${ }^{90}$ the costs of this distortion will ultimately be borne by the shareholders of investing firms. The question therefore becomes whether, given territoriality, equity holders are able to adopt a set of contractual provisions, at $t=0$, that would costlessly eliminate these efficiency costs. This section will discuss why such contracting solutions are unable to eliminate the distortion presented in this paper.

${ }^{90}$ See Section VA infra. 
The simplest solution for a firm would be to include in all loan contracts a provision stating that in the event of bankruptcy, universalism will apply to the assets of the firm. ${ }^{91}$ This, of course, would eliminate the distortion if the contract were enforceable. Because it is not possible to contract out of the bankruptcy laws, however, this solution is not available to firms.

Alternatively, if the state of nature, $\theta_{i}, i=A, B$, were verifiable, the firm could commit itself, through contract, to invest in $A$ if the state of nature is $\theta_{A}$, and in $B$ if it is $\theta_{B}$. This strategy is unavailable, however, because the state of nature is not verifiable by a court, making it impossible to write a contract that is contingent on this parameter.

We can also consider arrangements that constrain the discretion of the firm concerning future borrowing. One possibility would be for the firm to commit at $t=0$ to continue to borrow in the future only from creditors from the same country as its existing debt. This approach faces several problems. The first problem is that it would impose a cost of its own if domestic capital markets are not large enough to supply all the capital that might be necessary in the future. Second, when foreign investment is undertaken, some foreign borrowing might be beneficial, either because it might provide a good hedge for foreign exchange risks or because it might offer advantageous terms. And, indeed, when foreign investments are made, it might be impossible to prevent the firm from getting creditors in that foreign country; for example, the company might inevitably have some tort creditors and supply creditors.

Alternatively, in our two-country model, a firm can avoid the identified distortion by committing to always keep one-half of its debt in $A$ and onehalf in $B$. (With such a commitment, the firm will be able to get the same interest rate discount no matter which country it invests in, thereby eliminating the distortion.) In a world of many countries, such an arrangement would require a company to divide its debt equally among all the countries in which it might wish to invest in the future, and such an arrangement would clearly be very costly and impractical.

Another possible solution to consider is for the $t=0$ loan contract to make the interest rate on that contract depend on future investment behavior. For example, the contract might say that if the firm borrows abroad, the interest rate will increase. As a practical matter, such a contract poses such large informational problems that it is difficult to imagine it actually being

${ }^{91}$ Rasmussen proposes a contractual version of universalism. "If a firm were to place a provision in its corporate charter stating that it would file for bankruptcy only in a certain jurisdiction, which would then handle the bankruptcy proceeding according to its own law, all creditors of the firm should be bound by this choice of forum provision." Rasmussen, supra note 11 , at 1 . 
written. The range of possible future investments and the uncertainty about the riskiness of future ventures, the amount borrowed, the timing, and the location make a contingent contract improbable. ${ }^{92}$

A borrower could, of course, offer a security interest to the initial borrower. In some cases this may offer relief from the problem we have discussed, but in many cases it will not. First, there may not be enough collateral to fully secure the initial loan. If there is enough collateral, acquiring debt that is secured rather than unsecured may be inefficient for other reasons and may not, therefore, offer a solution to the problem presented in this paper. Finally, in a transnational bankruptcy, it may not be easy to be certain that one's loan is secured. The requirements for securing and perfecting collateral may vary from country to country, and a creditor may find that the jurisdiction with control over the assets will not view them as secured..$^{93}$ This uncertainty will, of course, undermine the benefits of acquiring a security interest.

Finally, a contract that requires renegotiation of the existing contract prior to any foreign borrowing might be considered. This solution, however, would leave a holdout problem, as the lender could demand a large share of the expected rents from any future investment.

Thus, it seems that private contracting cannot be relied on to completely eliminate the distortion. For this reason, the distortion should be taken into account when designing national and international transnational bankruptcy arrangements.

\section{The Political Economy of Territorialism}

At first glance it may seem that while there is a temptation to hurt foreign creditors ex post, the fact that there is no incentive to do so ex ante would lead countries to commit to universalism ex ante. As shown below, however, this is not the case. This section explores the political economy dimension of territorialism. ${ }^{94}$ First, we demonstrate that the ultimate cost of

92 Informational problems also frustrate a number of more complex contracting solutions. For example, one could imagine a contract in which the $t=0$ creditor is granted a put option that could be exercised if the debtor invests abroad. If properly crafted, this option could precisely offset the distortion, leading to an efficient distribution of assets. Like the simpler interest rate contingency discussed in the text, however, informational constraints make it impossible to use a put option to eliminate the distortion.

${ }_{93}$ See, for example, In re Toga Mfg., Ltd., 28 B.R. 165, at 168-69 (Bankr. E. D. Mich. 1983) (" "The American creditor] is thus a lien creditor and, as such, is recognized as holding a secured claim. ... Under Canadian law, on the other hand, [he] would most likely be considered an 'ordinary creditor' ").

94 There has been considerable recent work on the political economy of international trade. Our comments in this section are in that vein. See Warren F. Schwartz \& Alan O. Sykes, Toward a Positive Theory of the Most Favored Nation Obligation and Its Exceptions in the WTO/GATT System, 16 Int'l Rev. L. \& Econ. 27, passim (1996) (applying public choice 
the distortion is borne by firms and their shareholders. Then we analyze the reasons why a country would wish to be territorialist despite the costs that territorialism imposes. Finally, we propose a solution to the problem that allows the global community to achieve universalism without either a cumbersome process of international negotiation or the risk of defection by one or more countries.

\section{A. Who Bears the Cost of the Distortion?}

We have shown that territoriality leads to inefficient investment decisions. This implies a reduction in global efficiency and, therefore, global welfare. This section will demonstrate that it is foreign firms that are hurt by the territorial policy-they bear the cost of the inefficiency.

We demonstrated above that territorialism by one country, $A$, distorts the investment decisions of firms in another country, $B$. Because we have assumed competitive capital markets, $B$ 's creditors will not be hurt. These creditors choose a rate of interest ex ante such that they receive the world rate of interest in expectation. While these creditors may win or lose in particular cases ex post, they will be neither better nor worse off ex ante. Any interest rate discount obtained at $t=2$ amounts to a transfer from the $t=$ 0 creditor to the $t=2$ creditor in the event of bankruptcy. The $t=0$ creditor will take this into account and charge an interest rate that, at $t=0$, leaves it with the world rate in expectation after the $t=2$ decisions of the borrower are taken into account.

The only other parties available to bear the cost are the shareholders of the firm from $B$. Overall, they will pay the world rate for funds in expectation, with the "discount" available at $t=2$ being offset by a higher rate at $t=0 .{ }^{95}$ The inefficient allocation of capital will lead, of course, to a lower return for the firm.

Because the firms affected by country $A$ 's territorialism are the firms of country $B$, there is no constituency within country $A$ demanding universalism. Firms in country $A$ would like to ensure that universalism governs in country $B$ but are not concerned with the law in their own country. For this reason, despite the fact that universalism represents a more efficient global regime, there is little pressure on governments to adopt such a policy.

\footnotetext{
theory to the existence of discriminatory tariffs and exceptions to the GATT most-favorednation obligation); Alan O. Sykes, Protectionism as a "Safeguard": A Positive Analysis of the GATT "Escape Clause" with Normative Speculations, 58 U. Chi. L. Rev. 255 (1991); Alan O. Sykes, The Economics of Regulatory Protectionism and Its Implications for Trade Regulation: The WTO and Other Systems (mimeographed, Univ. Chicago 1997).

${ }^{95}$ The discount available at $t=2$ may not be fully offset by the $t=0$ interest rate premium if the creditor is unable, at $t=0$, to identify firms that will later become multinational enterprises.
} 


\section{B. The Benefit to a Country from Territoriality}

We now examine the potential benefits available to a country, $A$, from adopting a territorial regime. For analytical purposes, we will take $B$ 's behavior as given - thereby abstracting from all strategic interactions between the two countries. These interactions are important and are discussed in the next section.

As we have shown, by adopting a territorialist regime, $A$ distorts the decisions of $B$ 's firms. Assuming that $A$ does not care about the welfare of $B$ 's citizens and assuming that the shareholders of $B$ 's firms are all citizens of $B$, this welfare cost is not relevant to $A$ 's decision. ${ }^{96}$

At first glance, it may appear that territoriality benefits $A$ 's creditors by giving them more in the event of bankruptcy. We have seen, however, that this is not the case. Lenders get the world rate, regardless of the regime in place. By favoring them in bankruptcy, $A$ simply reduces the amount they earn in the nonbankruptcy state.

While the benefit to local creditors is not present, the analysis reveals two other benefits. The first is that by becoming territorialist, $A$ will attract investment by $B$ 's firms. This is precisely the effect of the territorialist policy that leads to the global distortion. Attracting additional investment will be welfare enhancing for a country if there are nontrivial spillovers to investment. For example, the investing firm may not be able to capture the full surplus created by its transactions with local suppliers and workers. There may be a transfer of technology or management skills (that is, human capital) for which the firm cannot capture payment; there may be certain public good elements to the firm's activities, such as paving roads or public service activities; and so on. If these spillovers are significant, $A$ may have a reason to attract the investment of $B$ 's firms even if $B$ is a more efficient location.

An additional benefit to $A$ from a territorial regime stems from the borrowing decision of firms. Under unilateral territorialism, $A$ will attract more borrowing for the same reasons it attracts investment-the distortion leads to both investment and borrowing in $A$. If there are spillovers to providing credit, then there would be some incentive for a country to attempt to become the source for more loans.

\section{Reciprocity}

Our analysis allows us to consider the importance of reciprocity with respect to universality. The case law on transnational bankruptcies has often

\footnotetext{
${ }^{96}$ It is, of course, artificial to assume that all of $B$ 's shareholders are citizens of $B$. To the extent that citizens of $A$ are also shareholders of $B$, the benefits of territorialism are reduced, and may even be negative.
} 
discussed the importance of reciprocity, though there is currently no consensus on the issue.

In Hilton v. Guyot, ${ }^{97}$ the United States Supreme Court stated that the United States should only give effect to a French judgment to the same extent that France would give effect to an American judgment. ${ }^{98}$ The Court was not seeking to influence the policies of other countries, nor was the ruling intended to retaliate against those nations that refused to enforce American judgments. Instead, the Court based its decision on "the broad ground that international law is founded upon mutuality and reciprocity." 99 The Third Circuit, in Remington Rand Corp. v. Business Systems Inc. ${ }^{100}$ (Remington I) and Kilbarr Corp. v. Business Systems Inc. ${ }^{101}$ (Remington II), appeared to be applying a reciprocity requirement. Although the court did not explicitly state that reciprocity is required, the cases suggest that the Third Circuit may require reciprocity. ${ }^{102}$ Most courts, however, do not demand reciprocity. In addition, it is not universally supported by commentators and is not required by Section 304. For example, Cunard S.S. Co. v. Salen Refer Services $A B^{103}$ states that "while reciprocity may be a factor to be considered, it is not required as a condition precedent to the granting of comity." 104

As we have shown, each country, acting individually, will prefer to be territorialist. The cost of territorialism in $A$ is borne by foreign firms and their shareholders, a group whose welfare loss is not a concern to $A$. Country $A$ may benefit from its territorialism to the extent that there are spillovers to investment and lending. In other words, citizens of $A$ benefit from the policy, while citizens of $B$ suffer the costs.

Acting individually, therefore, both $A$ and $B$ will be induced to act in a way that would reduce total global welfare. This result provides a rationale for a reciprocity requirement. Country $A$, for example, could adopt a policy of universalism toward $B$ if and only if $B$ adopts a universalist policy toward $A$. This policy would work well only if $B$ faces potential losses should $A$ adopt a territorialist regime. Such would be the case only if $B$ had firms with significant domestic debt and investment opportunities (now or in the future) in $A$.

97159 U.S. 113 (1895).

${ }^{98}$ Id. at $211-28$.

${ }^{99} I d$. at 228.

100830 F.2d 1260 (3d Cir. 1987).

101990 F.2d 83 (3d Cir. 1993).

${ }^{102}$ Remington II, 830 F.2d, at 1273 (3d Cir. 1987).

103773 F.2d 452 (2d Cir. 1985).

104 Id. at 460 (citing Johnson v. Compagnie Générale Transatlantique, 242 N.Y. 381, 387 (1926)). 
If there are significant investment flows in both directions, such as between the United States and Europe, then a policy of reciprocity would be an effective way to achieve universality. On the other hand, if country $B$ is a developing country with few multinational firms headquartered in that country, territorialism by $A$ would be virtually costless to $B$. A policy of reciprocity may not work under such circumstances, and other avenues such as treaties or side payments would have to be explored.

\section{Conclusion}

This paper has identified some effects of the rules governing transnational bankruptcies. The analysis has demonstrated that a regime of territoriality generates an efficiency cost that has not previously been recognized. Specifically, territoriality creates ex ante distortions in firms' locational decisions. In contrast, universality acts to allow the distribution of assets without distortion, leading to more efficient investment patterns.

The paper has also identified the winners and losers from territoriality. Among other things, it has been shown that even though territoriality reduces overall global welfare, a country, taking the behavior of other countries as given, may benefit from territoriality at the expense of foreign firms. Reciprocity represents a form of international coordination that may facilitate universalism, although in some situations it may be that universalism can only be achieved through formal international agreement.

\section{BIBLIOGRAPHY}

Adler, Barry E. "Financial and Political Theories of American Corporate Bankruptcy." Stanford Law Review 45 (1993): 311-46.

Adler, Barry E. "A Re-examination of Near Bankruptcy Investment Incentives." University of Chicago Law Review 62 (1995): 575-606.

Alford, Duncan E. "Basle Committee Minimum Standards: International Regulatory Response to the Failure of BCCI." George Washington Journal of International Law and Economics 26 (1992): 241-91.

Baird, Douglas G. "The Uneasy Case for Corporate Reorganizations." Journal of Legal Studies 15 (1986): 127-47.

Balz, Manfred. "The European Convention on Insolvency Proceedings." American Bankruptcy Law Journal 70 (1996): 485-531.

Bebchuk, Lucian A. "The Effects of Chapter 11 and Debt Renegotiation on Ex Ante Corporate Decisions." Discussion Paper No. 104. Cambridge, Mass.: Harvard Law School Program in Law and Economics, 1994.

Bebchuk, Lucian A., and Picker, Randall C. "Bankruptcy Rules, Managerial Entrenchment, and Firm-Specific Human Capital." John M. Olin Program in Law and Economics Working Paper. 2d Ser., No. 16. Chicago: University of Chicago Law School, 1993. 
Boshkoff, Douglass G. "Some Gloomy Thought concerning Cross-Border Insolvencies." Washington University Law Quarterly 72 (1994): 931-41.

Caves, Richard E. Multinational Enterprise and Economic Analysis. 2d ed. Cambridge: Cambridge University Press, 1996.

Desai, Mihir A. "A Multinational Perspective on Capital Structure Choice and Internal Capital Markets." Unpublished manuscript. Cambridge, Mass.: Harvard University, Department of Economics, 1997.

Farber, Daniel A., and Frickey, Philip P. "The Jurisprudence of Public Choice." Texas Law Review 65 (1987): 873-1019.

Fletcher, Ian. "Cross-Border Cooperation in Cases of International Insolvency: Some Recent Trends Compared." Tulane Civil Law Forum 6-7 (1991-92): 171-85.

Gaa, Thomas M. "Harmonization of International Bankruptcy Law and Practice: Is It Necessary? Is It Possible?' International Lawyer 27 (1993): 881-909.

Guzman, Andrew T. "Why LDCs Sign Treaties That Hurt Them: Explaining the Popularity of Bilateral Investment Treaties." Virginia Journal of International Law 38 (1998): 639-88.

Guzman, Andrew T. "Capital Market Regulation in Developing Countries: A Proposal." Virginia Journal of International Law 39 (1999): 607-45.

Hoffmann, Leonard. "Cross-Border Insolvency: A British Perspective." Fordham Law Review 64 (1996): 2507-20.

Nadelmann, Kurt H. "Discrimination in Foreign Bankruptcy Laws against Nondomestic Claims." American Bankruptcy Law Journal 47 (1973): 147-55.

Nadelmann, Kurt H. "Rehabilitating International Bankruptcy Law: Lessons Taught by Herstatt and Company." New York University Law Review 52 (1977): $1-35$.

Nielsen, Anne; Sigal, Mike; and Wagner, Karen. "The Cross-Border Insolvency Concordat: Principles to Facilitate the Resolution of International Insolvencies., American Bankruptcy Law Journal 70 (1996): 533-62.

Powers, Timothy E., and Mears, Rona R. "Protecting a U.S. Debtor's Assets in International Bankruptcy: A Survey and Proposal for Reciprocity." In International Loan Workouts and Bankruptcies, edited by Richard A. Gitlin and Rona R. Mears. Vol. 1, pp. 1056-1102. Stoneham, Mass.: Butterworth Legal Publishers, 1987.

Rasmussen, Robert K. “'Debtor's Choice: A Menu Approach to Corporate Reorganization." Texas Law Review 71 (1992): 51-121.

Rasmussen, Robert K. "A New Approach to Transnational Insolvencies." Michigan Journal of International Law 19 (1997): 1-36.

Schwartz, Alan. "Bankruptcy Workouts and Debt Contracts." Journal of Law and Economics 36 (1993): 595-632.

Schwartz, Warren F., and Sykes, Alan O. "Toward a Positive Theory of the Most Favored Nation Obligation and Its Exceptions in the WTO/GATT System." International Review of Law and Economics 16 (1996): 27-51.

Sigal, Mike, et al. "The Law and Practice of International Insolvencies, including a Draft Cross-Border Insolvency Concordat.' 1994-95 Annual Survey of Bankruptcy Law 1 (1994): 138-154. 
Sykes, Alan O. "Protectionism as a "Safeguard": A Positive Analysis of the GATT “'Escape Clause'” with Normative Speculations." University of Chicago Law Review 58 (1991): 255-305.

Sykes, Alan O. "The Economics of Regulatory Protectionism and Its Implications for Trade Regulation: The WTO and Other Systems.' Unpublished manuscript. Chicago: University of Chicago Law School, 1997.

Tagashira, Shoichi. "Intraterritorial Effects of Foreign Insolvency Proceedings: An Analysis of "Ancillary" Proceedings in the United States and Japan." Texas International Law Journal 29 (1994): 1-38.

Westbrook, Jay L. "Choice of Avoidance Law in Global Insolvencies." Brooklyn Journal of International Law 17 (1991): 499-538.

Westbrook, Jay L. "Theory and Pragmatism in Global Insolvencies: Choice of Law and Choice of Forum." American Bankruptcy Law Journal 65 (1991): 457-90.

Westbrook, Jay L. "Creating International Insolvency Law." American Bankruptcy Law Journal 70 (1996): 563-74.

Westbrook, Jay L. "The Lessons of Maxwell Communications." Fordham Law Review 64 (1996): 2531-41. 